\author{
Aleksandra Szczerba-Zawada \\ The Jacob of Paradyż University of Applied Sciences in Gorzów Wielkopolski \\ szczerba.aleksandra@gmail.com
}

\title{
The President of the European Council and Other Formats of Presidency in the European Union: (Un)Constructive Ambiguity in the EU Political System
}

\author{
Przewodniczący Rady Europejskiej \\ a inne formaty unijnej prezydencji: \\ (nie)konstruktywna niejednoznaczność kompetencyjna
}

\section{SUMMARY}

The semi-permanent presidency of the European Council, introduced by virtue of the Lisbon Treaty, has restructured the organizational space of the EU presidency, becoming the new leadership centre in the EU institutional engineering. Consequently the institutional balance in the whole system has been changed, however without a clear jurisdictional delimitation of the competences between the components of this multi-centre political system. In the imprecisely defined conceptual framework of the new space of the EU presidency, there exists a question of the possibility of various levels multiplying and overlapping with each other, giving rise to a potential conflict of power in this area.

The aim of this article is to provide the assessment of the scope of implications of the introduced changes on the basis of analysis of the structural relations between the President of the European Council and his institutional partners in the EU hybrid presidency system, i.e. the President of the European Commission, the High Representative of the Union for Foreign Affairs and Security Policy and the rotating country presidency.

Keywords: EU Presidency; President of the European Council; High Representative of the Union for Foreign Affairs and Security Policy; President of the European Commission

The Presidency of the European Union, defined as an institutionalised procedure for leading the European Union, that is assuming the role of its leader 
combined with an at least alleged political responsibility ${ }^{1}$, has been transformed as a result of the Lisbon reform, which gave it a hybrid character. As a result of the changes, the EU presidency is exercised in two ways, both in the most traditional dimension, that is by the Member States within the framework of a rotating presidency, and in the denationalised dimension, in which the presidency over a specific institution is entrusted for the duration of a specific term to a personal substrate of said institution ${ }^{2}$. However, after the Lisbon Treaty the semi-permanent presidency mechanism, encompassing currently also the Foreign Affairs Council and the European Council, was markedly broadened.

Institutionalized presidency of the European Council, by restructuring the organizational space of the EU presidency ${ }^{3}$, has undoubtedly changed the institutional balance in the whole EU political system. This statement, as right as obvious - such a consequence of the creation of the position of the permanent President of the European Council was anticipated as early as at the stage of granting formal and legal shape of this concept in the Constitutional Treaty ${ }^{4}$ - justifies the attempt below to analyse the implications of the introduced solutions, on the basis of identification of the relational potential ${ }^{5}$ of this new leadership centre in the post-Lisbon system of presidency in the European Union. When introducing the new levels of presidency into the EU institutional engineering - that is the President of the European Council and the High Representative of the Union for Foreign Affairs and Security Policy and reforming the existing formats of the EU presidency (the changed 18-month-long group presidency of the Council) - the Lisbon Treaty was not able to make a clear jurisdictional delimitation between the components of this multi-centre system. Consequently, in the imprecisely defined conceptual framework of the new space of the EU presidency, there continues to exist a question of the possibility and implications of various levels multiplying and overlapping with each other, which may give rise, if not so much to a potential conflict of power, then to the confusion in this area. Identification of qualitative consequences of creating the new permanent position of the President of the European Council, which arise - as it is justifiably raised in the doctrine - not from changing the way of electing the President of the European Council or the extension of his term but from the substantial (i.e. determined by a catalogue of treaty

${ }^{1}$ L. Jesień, The European Union Presidency. Institutionalized Procedure of Political Leadership, Bern 2013, DOI: http://dx.doi.org/10.3726/978-3-0351-0531-5, p. 24.

${ }^{2}$ A. Nowak-Far, Przewodnictwo w organizacjach międzynarodowych - przeglad praktyki, [in:] Prezydencja w Unii Europejskiej. Instytucje, prawo i organizacja, red. A. Nowak-Far, Warszawa 2010, pp. 22-23.

${ }^{3}$ A. Szczerba-Zawada, Przewodniczący Rady Europejskiej, czyli o postlizbońskiej formule przewodnictwa w Radzie Europejskiej, „Przegląd Sejmowy” 2014, nr 4.

${ }^{4}$ J.W. Sap, The European President, "European Constitutional Law Review" 2005, Vol. 1, p. 48.

${ }^{5}$ A. Nowak-Far, Przewodnictwo w organizacjach międzynarodowych..., p. 165. 
prerogatives of the President of the European Council) aspects of conceptualisation of the idea of the presidency of the European Council which supplement these formal matters ${ }^{6}$, is consequentially necessary not only to capture the essence of the new formula of presiding over work of this EU institution.

As a result of the research problem being defined in such a way, the structural relations between the President of the European Council and his institutional partners in the EU two-way presidency system ${ }^{7}$, meaning the President of the European Commission, the High Representative of the Union for Foreign Affairs and Security Policy and the national rotating presidency, will be analysed.

\section{THE PRESIDENT OF THE EUROPEAN COUNCIL AND THE PRESIDENT OF THE EUROPEAN COMMISSION}

The concerns about the consequences of an appearance of another centre of power that rivals the President of the European Commission in the form of the President of the European Council constituted the basis for the opposition of smaller Member States against the project of introduction of elected presidency in the European Council ${ }^{8}$. It was argued that the permanent President of the European Council along with the High Representative of the Union for Foreign Affairs and Security Policy will not only weaken the system of rotating presidency, and thereby diminish the importance of the principle of equality of the EU Member States which constitutes the foundation of the European Union, but also strengthen the intergovernmental aspect of the EU at the expense of a supranational dimension of the integration through undermining the position of the Commission President ${ }^{9}$. For these reasons, opponents of the idea of semi-permanent presidency of the European Council called for retaining, in principle, the existing presidency model with introduction of certain changes into it.

The avoidance of the rivalry between the Presidents of the two institutions was a highly complex task requiring that a balanced solution be found or that one of two opposing proposition be entirely rejected. With the volume of the EU competences not being enlarged, it is not basically possible to assign them in such a way to introduce a strong President of the European Council and at the same

${ }^{6}$ J. Galster, Równowaga instytucjonalna jako kategoria doktrynalna, orzecznicza i normatywna. Studium zasady Unii Europejskiej, Toruń 2008, p. 174.

${ }^{7}$ J.W. Sap, op. cit., pp. $48-49$.

${ }^{8} \mathrm{~K}$ Wójtowicz, Projekt Traktatu ustanawiajacego Konstytucję dla Europy - podstawy ustroju i porzadku prawnego Unii Europejskiej, „Przegląd Sejmowy” 2004, nr 2, p. 32; P. Craig, The President of the European Council, [in:] Europe's Constitutional Challenges in the Light of the Recent Case Law of National Constitutional Courts. Lisbon and Beyond, eds. J.M. Beneyto, I. Pernice, Baden-Baden 2011, DOI: http://dx.doi.org/10.5771/9783845233109-203, p. 210.

${ }^{9}$ L. Jesień, op. cit., pp. 94-95. 
time strengthen the position of the President of the European Commission ${ }^{10}$. The currently applicable primary and secondary law regulations governing the status of the President of the European Council and the President of the Commission seem to be an expression of a compromise, which seeks common denominator for diverse views regarding the EU presidency, thereby - the EU executive power. The solution that was finally adopted was supposed to satisfy the demands by introduction of one-person presidency model in the European Council with simultaneous dispelling of fears about the future position of the Commission President ${ }^{11}$. However, competences of both the presidency formats failed to be clearly divided, therefore the shape of the EU executive will be determined not only by the normative aspect but also the factual dimension ${ }^{12}$, especially in those areas where the mutual relations of both the Presidents are affected by overlapping influence.

In the search for those fields of mutual correlation or intersection between the two offices, determined by relevant competence norms and inherently burdened with the risk of conflict or misunderstanding, one must, first of all, take into consideration the assignments determined by the Treaty for both the Presidents which go beyond their managerial obligations related to presiding over the work of the European Commission and the European Council, respectively. Therefore their activity in the field of the external representation of the European Union continues to be an object of interest, as both the President of the European Council and the Commission President play an important role in it, although as shown by the practice of integration processes, the newly appointed office of the President of the European Council - in many cases also in the field of EU internal policies entered the area of activity of the Commission presidency, often overshadowing the importance of the Commission President ${ }^{13}$. From formal and legal perspective, there should not be any conflict of power between the two actors, neither in the area of internal EU actions (the President of the European Council was not, in essence, equipped with powers concerning this area of EU policies, although in the past few years he has been appointed head of several working groups established to study specific issues of EU integration and to deliver proposals of their resolutions $^{14}$ ) nor in the external area of its activity, as they have different scopes of EU representation. The Commission President represents the EU with regard to all

${ }^{10}$ R. Grzeszczak, Władza wykonawcza w systemie Unii Europejskiej, Warszawa 2011, p. 188.

${ }^{11}$ J.W. Sap, op. cit., p. 48.

${ }^{12}$ P. Craig, op. cit., p. 211; P. Curtin, Executive Power of the European Union. Law, Practices and the Living Constitution, Oxford - New York 2009, p. 95.

${ }^{13}$ It is noticed by D. Dinan, Governance and Institutions: Implementing the Lisbon Treaty in the Shadow of the Euro Crisis, "Journal of Common Market Studies" 2011, Vol. 49, DOI: http://dx.doi. org/10.1111/j.1468-5965.2011.02183.x, pp. 105-106.

${ }^{14}$ H. de Waele, H. Broeksteeg, The Semi-Permanent European Council Presidency: Some Reflections on the Law and Early Practice, "Common Market Law Review" 2012, Vol. 49, pp. 1057-1058. 
aspects of external relations except for the Common Foreign and Security Policy and "any specific sectoral policies falling within the scope of the external action of the Union"15. On the other hand, Art. 15(6) TEU, defining the responsibilities of the President of the European Council in the area of the Union's external relations, narrows down said scope to the area of Common Foreign and Security Policy. Such a legal solution, despite suggesting synergy between the two representation centres of the EU on the international arena, does not eliminate the risk of misunderstandings, as most of the areas included in the competencies of the European Commission raises implications in the external area of the Union's activity ${ }^{16}$. In this context, the practice of external representation of the Union placed in the legal framework introduced by the Treaty of Lisbon may make it possible for the President of the European Council and the Commission President to block their competence freedom in the area of external dimension of the economic policy. This will apply, first and foremost, to the EU representation during G-20 and G-8 meetings that are performed by both the actors if they are held on the highest level of political leadership - the prime ministers and the Presidents ${ }^{17}$. The importance of these meetings and the political weight of the matters discussed and decisions reached on these summits may add fuel to the competitive tendencies between the two positions, if each of them attempts to highlight the authority of their office, leading to unavoidable discrepancy in the voice of the EU occurring in the place of one coherent position.

Such a factual and legal state poses a serious risk of formation and parallel existence of two competitive centres of power in the European Union while their being equipped with general and imprecisely defined catalogues of treaty assignment and prerogatives may lead to difficulties in determining and executing their respective scopes of responsibilities ${ }^{18}$. In particular, negative implications for both the actors may be carried by imprecise formula about the EU representation by the President of the European Council in the CFSP area "at his level and in that capacity". It does not answer the question whether the level of the President of the European Council is also the level of the Commission President, who is a member just like the Heads of State or Government and its President, being, similarly

${ }^{15}$ European Parliament resolution of 7 May 2009 on the impact of the Treaty of Lisbon on the development of the institutional balance of the European Union (O.J. 2010, C 212E/12. 2008/2073(INI)), point 62 .

${ }^{16}$ M. Krystyniak, Rola przewodniczacego Rady Europejskiej w stosunkach zewnętrznych UE, „Biuletyn Polskiego Instytutu Spraw Międzynarodowych” 2003, nr 61, p. 951.

17 J. Peterson, A. Byrne, N. Helwing, International Interests: the Common Foreign and Security Policy, [in:] The Institutions of the European Union, eds. J. Peterson, M. Shackleton, Oxford 2012, p. 299.

${ }^{18}$ S. Dudzik, System instytucjonalny Unii Europejskiej w Konstytucji dla Europy. Zarys problematyki, [in:] Konstytucja dla Europy. Przyszły fundament Unii Europejskiej, red. S. Dudzik, Kraków 2005, pp. 229-230. 
to the last one, deprived of the right to vote in case the European Council enters the voting procedure. May their positions be construed as equal to each other for the sake of that regulation? ${ }^{19}$ If not, will such a decrease in importance of the Commission President in the forum of the European Council not carry negative implications for the quality of negotiation procedures and the mechanisms aimed at reaching the consensus, in whose creation the authority of the head of the Commission oftentimes played a key role? ${ }^{20}$ Effective fulfilment of the obligation to act to reach coherence and consensus by the President of the European Council during its work would compensate this potential marginalisation of the importance of the Commission President, however it requires the previous, being filled with practical content of imprecise legal regulation.

A solution to these problems may be correlation of the election of the President of the European Council with the election of the President of the European Commission ${ }^{21}$ or integration of these two offices. A return to this most radical concept of reforming the EU presidency system is not only probable in the future debate on the EU institutional structures but also feasible in the current legal state $^{22}$. The current treaty formula opposing the holding of the European Council President's office along with the country public function does not constitute an obstacle against simultaneous assumption of presidency in the European Council and the European Commission ${ }^{23}$. Decision not to introduce such a solution can only be dictated by the fear about the effectiveness of such an accumulated presidency, threatened by quite different objectives of the two institutions ${ }^{24}$ - the European Commission is, after all, a supranational institution, supporting the interest of the Union as a whole, while the European Council is a representation forum for the Member States and the diverse areas of competence of the two offices that are determined by them.

${ }^{19}$ K. Witkowska-Chrzczonowicz, Prezydencja w Radzie Unii Europejskiej, [in:] M. Czyżniewski, K. Witkowska-Chrzczonowicz, Prezydencja Republiki Czeskiej w Radzie Unii Europejskiej. Studium prawno-politologiczne, Warszawa 2011, p. 63.

${ }^{20}$ A. Szczerba-Zawada, Pozycja ustrojowa Rady Europejskiej w systemie instytucjonalnym Unii Europejskiej, Warszawa 2013, p. 125.

${ }^{21}$ P. Świeboda, System instytucjonalny Unii Europejskiej w Traktacie z Lizbony - konsekwencje i wyzwania, [in:] Traktat z Lizbony - postanowienia, ocena, implikacje, red. K. Smyk, Warszawa 2008, pp. 105-106.

${ }_{22}$ J. Werts, The European Council, London 2008, p. 159; F. Eggermont, The Changing Role of the European Council in the Institutional Framework of the European Union. Consequences for the European Integration Process, Cambridge - Antwerp - Portland 2012, p. 29.

${ }^{23}$ H. de Waele, H. Broeksteeg, op. cit., p. 1046.

${ }^{24}$ J. Werts, op. cit., p. 159; F. Eggermont, op. cit., p. 29. 


\section{THE PRESIDENT OF THE EUROPEAN COUNCIL AND \\ THE HIGH REPRESENTATIVE OF THE UNION FOR FOREIGN AFFAIRS AND SECURITY POLICY}

The responsibilities assigned to the President of the European Council regarding the representation of the EU in matters related to the foreign and security policy confirms his functional introduction into the frameworks of the EU executive power. At the same time, the Lisbon reform leads to the formation of an executive centre which is autonomised with regard to the Member States - the office of the High Representative of the Union for Foreign Affairs and Security Policy, presiding over works of the Foreign Affairs Council and responsible primarily for pursuing the EU foreign policy. Equipping the both elements of the EU presidency system in flagship competencies of executive power ${ }^{25}$ implies eclecticism of legal regulation in this area ${ }^{26}$, deepening the split nature of this area of power in the EU. Having taken into consideration the last statement, one must point out that problematic character of such a solution lies not so much in the extension of the institutional structures of the EU executive but in the imprecise delimitation of powers granted to them. The brief and general stipulation of Art. 15(6) TEU providing that the function of representation of the EU in external matters regarding the Common Foreign and Security Policy be performed by the President of the European Council "at his level and in that capacity [...] without prejudice to the powers of the High Representative of the Union for Foreign Affairs and Security Policy", despite being indicative of an attempt made by the creators of the Treaties to avoid potential jurisdictional friction arising out of a parallel powers related to the EU representation in the external area of the High Representative of the Union for Foreign Affairs and Security Policy, does not constitute a sufficient protection against crossing of the powers of the two centres of EU presidency, does not explain the character of their mutual relations in said area $^{27}$, nor does it define the technical or organisational questions related to their co-existence, such as the size of their staff or the principles of financing their activity ${ }^{28}$. As a consequence, equipping the President of the European Council with competencies in the area of the EU external actions in a situation where material powers related to the external representation are held under Art. 27(2) TEU by the High Representative of the Union for Foreign Affairs and Security Policy may also give rise to effects that are analogous to the lack of clear delimitation of powers between the President of the

${ }^{25}$ Art. 15(6) TEU; Art. 18(1) TEU; Art. 27(1) TEU.

${ }^{26}$ R. Grzeszczak, op. cit., p. 188.

${ }^{27}$ C. Rüger, A Position under Construction: Future Prospects of the High Representative after Treaty of Lisbon, [in:] The High Representative for the EU Foreign and Security Policy - Review and Prospects, eds. G. Müller-Brandeck-Bocqut, C. Rüger, Baden-Baden 2011, p. 214, 229.

${ }^{28}$ R Grzeszczk, op. cit., p. 199. 
European Council and the Commission President, i.e. leading to misunderstandings or conflicts of competencies between the two ${ }^{29}$.

The solution adopted in the Treaty of Lisbon in the field of external representation of the EU must be surprising especially in the light of the premises of the institutional reform in this area. Creation of a separate office of the High Representative of the Union for Foreign Affairs and Security Policy combining at the same time the function of the current High Representative for Common Foreign and Security Policy, the commissioner for external relations and the country presidency in the External Affairs Council, was supposed to eliminate the main inconvenience of structural fragmentation of CFSP environment - the rivalry between the European Commission and the high representative of the Union as well as between the high representative of the Union and the Member State exercising presidency for the influence over the shape of the EU external relations ${ }^{30}$, and thereby strengthen the coordination in the EU foreign policy and ensure its consistent representation on the international arena ${ }^{31}$. It is difficult to view the introduction of the new centre of power in this area in the form of the President of the European Council as a successful attempt to rationalise the existing mechanisms and structures without precise redistribution of the volume of competencies existing within it. Equipping the President of the European Council with powers to represent the $\mathrm{EU}$ in external affairs not only multiplies the organisation surroundings of the EU foreign policy and the area of its external actions but also strengthens the decision dichotomy that arises from intergovernmental nature of the Common Foreign and Security Policy and the supranational character of the EU actions on the international arena - the President of the European Council representing the EU on his level articulates the interests of the Heads of State or Government and not the supranational interest of the EU - the dichotomy which the reform of CFSP institutional facilities was supposed to be a medicine for ${ }^{32}$. One must not rule out that the Heads of State or Government, in particular the state of the current presidency, will seek to take advantage of this legal solution in their own interest, since other channels of their influence in the area of external relations have been blocked as a result of the Lisbon reform by depriving them of the leadership in two institutions that are of utmost importance in this field - the External Affairs Council and the European Council, and also by depriving them of the power to represent the EU in matters covered by the Common Foreign and Security Policy ${ }^{33}$, which

${ }^{29}$ J. Galster, A. Knade-Plaskacz, E pluribus unum. Koherencja UE jako organizacji międzynarodowej, [in:] Unia Europejska: zjednoczeni w różnorodności, red. C. Mik, Warszawa 2012, p. 31.

${ }^{30}$ P. Świeboda, op. cit., pp. 114-115.

${ }^{31}$ K. Witkowska-Chrzczonowicz, op. cit., p. 68.

${ }^{32}$ P. Świeboda, op. cit., pp. 114-115.

${ }^{33}$ Art. 18(1) TEU (Nice version). 
for many oftentimes constitute the only possibility to confirm their international position $^{34}$.

In the light of the results which the completed structural reform of the Common Foreign and Security Policy was supposed to contribute to achieve, a question arises how to ensure an appropriate level of coordination between different presidency levels in the presence of such an ambiguous institutional instrumentarium? In other words, how to correlate the activities undertaken within the CFSP framework by the President of the European Council and the High Representative of the Union for Foreign Affairs and Security Policy? Both of them represent the Union in the area of the Common Foreign and Security Policy, although the President does that "at his level and in that capacity". The attempt to fill the unclear treaty provisions regarding these levels with content that is sufficiently explicative so that they could be given an operative value leads to the conclusion about assigning the level of representation of the President of the European Council to the level of the Heads of State or Government, the level of the high representative of the Union to the lower ministerial rank ${ }^{35}$. Is or can such a division of layers of representation be in any way indicative of the assessment of their positions in the presidency system in the area of external relations? To put it plainly, does it signify a hierarchisation of their positions and if so, how is it directed? Taking into consideration the above-mentioned levels of representation undoubtedly suggests a leading role of the President of the European Council, especially when one takes into account the European Council's competence that is fundamental for programming the Common Foreign and Security Policy ${ }^{36}$ and defining strategic objectives and interests of the EU in the area of external actions ${ }^{37}$, whose decisions the High Representative of the Union for Foreign Affairs and Security Policy is by treaty obliged to ensure to execute ${ }^{38}$. On the other hand, it is the High Representative of the Union for Foreign Affairs and Security Policy, not the President of the European Council, that makes contributions the development of CFSP by submitting his propositions and conducts this policy ${ }^{39}$. In addition, he presides over the Foreign Affairs Council ${ }^{40}$ - formation of the Council which is equipped by the Treaty with decision-making competencies in the area of the Common Foreign and Security Policy that are no less important than those of the European Council - as it "shall frame the Common Foreign and Security Policy and take the decisions necessary

${ }^{34}$ P. Świeboda, op. cit., p. 98.

${ }^{35}$ European Parliament resolution of 7 May 2009, point 62; The Treaty of Lisbon: A Second Look at the Institutional Innovations. Joint CEPS, EGMONT and EPC Study, Brussels 2010, p. 72.

${ }^{36}$ Art. 26 TEU.

${ }^{37}$ Art. 22 TEU.

${ }^{38}$ Art. 27(1) TEU.

${ }^{39}$ Art. 18(2) TEU.

${ }^{40}$ Art. 18(3) TEU. 
for defining and implementing it" ${ }^{41}$ and takes decision regarding the operational actions, should international situation require that ${ }^{42}$. The High Representative of the Union not only takes part in the work of the Council but also is a member of the European Commission and one of its vice-Presidents, responsible for the coherence of the EU external actions ${ }^{43}$. In all of these double or even triple roles, he is not only anchored in the Commission and the Council but also constitutes an EU office that is equipped with its own catalogue of competencies - the High Representative of the Union for Foreign Affairs and Security Policy has instruments, also of an executive character ${ }^{44}$, that are not available to the European Council. Such a legal solution encouraged assessment, formulated by some, that in the new EU presidency system, the permanent President of the European Council has not only smaller powers than the Head of State or Government that fulfilled that role so far but also holds a weaker position in the area of external relations than the High Representative of the Union for Foreign Affairs and Security Policy, performing oftentimes a purely representative role ${ }^{45}$. The assessment of the actual activity of the President of the European Council does not justify such a statement, though.

\section{THE PRESIDENT OF THE EUROPEAN COUNCIL AND THE ROTATING PRESIDENCY OF THE COUNCIL}

Entry into force of the Lisbon Treaty, and along with it the creation of a permanent President of the European Council had its implications also for the position of the national presidency in the EU political system. The problem of mutual relations between these centres of the EU presidency system is an issue of utmost importance, both normative and political. Their arrangement has a bearing on the holistic image of the presidency in the EU, deciding, and in essence co-deciding along with above-mentioned structural and competence-related connections in a multi-node network of the EU presidency, about its efficiency.

The Treaty of Lisbon, by installing the stable and full-time presidency of the European Council breaks strong ties between the presidency of the Council and the presidency of the European Council by eliminating from the legal transactions the existing stipulation of Art. 4 TEU (Nice version) under which the European Council assembled under the leadership of a Head of State of Government of

\footnotetext{
${ }^{41}$ Art. 26(2) TEU.

${ }^{42}$ Art. 28(1) TEU.

${ }^{43}$ Art. 18(3) TEU.

${ }^{44}$ The Treaty of Lisbon: A Second Look at the Institutional Innovations, pp. 72-73.

${ }^{45}$ M. Krystyniak, op. cit., p. 95; K. Kremczyńska, Nowe stanowiska wysokiego przedstawiciela Unii oraz przewodniczacego Rady Europejskiej w systemie instytucjonalnym UE, „Biuletyn Polskiego Instytutu Spraw Międzynarodowych”2009, nr 76, p. 2104.
} 
the Member State which presided at the time over the Council. It also deprived the national rotating presidency of other important powers through assigning these powers to the President of the European Council, thus marginalising it in the area of internal activity of the European Council but also, which seems even more afflictive to the Member States, in the area of the EU external relations ${ }^{46}$. As a consequence, the role of the Member States and the Heads of State or Government has been severely reduced in the post-Lisbon EU's leadership architecture ${ }^{47}$. At the same time the treaty solutions were introduced to protect the interests of the Member States in the reformed EU presidency system by introducing the requirement of close cooperation between the rotating presidency and the President of the European Council (as well as the Commission President and the High Representative of the Union for Foreign Affairs and Security Policy $)^{48}$.

Said regulations of the institutionalised aspects of presidency do not determine in advance, however, the actual relations between the rotating presidency and the permanent President of the European Council, whose formation depends essentially on their practical dimension ${ }^{49}$. As a consequence, they do not eliminate the risk of antagonisms between the two centres of the EU presidency that are so disadvantageous from the EU's point of view. Hidden in them is also a potential for disputes and tensions, however it is not determined by overlapping scopes of competences of the rotating presidency and the President of the European Council to such an extent as in case of relations between the President of the European Council and the Commission President or the High Representative of the Union for Foreign Affairs and Security Policy. Rather it becomes an ambition conflict related to the decreasing position - and thereby the prestige - of the former in the organisational system of the European Union as a result of introducing semipermanent presidency of the European Council. Protocol-related and political dissonances, caused by deprivation of the Head of State or Government from the presidency country of the leadership in the European Council, may constitute one of the sources of potential tensions, especially if the new President does not want or is not able to make concessions to the Head of State of Government of the presidency country, necessary to work out a compromise with the Member States ${ }^{50}$. A generator of misunderstandings may also be the deprivation of the rotating pres-

${ }^{46}$ More on this issue see S. Bunse, C. Klein, What's Left of the Rotating Presiency? The Future of 'National' Presidencies, [in:] The European Council and European Governance. The Commanding Heights of the EU, eds. F. Foret, Y.-S. Rittelmeyer, London - New York 2014, pp. 79-81.

${ }^{47} \mathrm{C}$. Closa, Institutional Innovation in the EU: The 'Permanent' Presidency of the European Council, [in:] The EU's Lisbon Treaty. Institutional Choices and Implementation, ed. F. Laursen, Farnham 2012, p. 125.

${ }^{48}$ E.g. Art. 15(6)(b) TEU; Art. 16(6) TEU.

${ }^{49}$ H. de Waele, H. Broeksteeg, op. cit., p. 1060 et seq. It has been proved by S. Bunse, C. Klein, op. cit., p. 82 et seq.

${ }^{50}$ P. Świeboda, op. cit., p. 100. 
idency of the Council, as a result of introduced changes, of many benefits related to the presidency in the European Council, including the chances of deep - "inner" one could say - recognition of the functioning principles of the EU institutional engineering, including its highest decisive level ${ }^{51}$ or the possibility to highlight one's qualitative impact on the direction of the integration processes through the rotating presidency's agenda-setting power ${ }^{52}$, although these and other benefits of rotating presidency gradually dwindled in significance in the years preceding the entry into force of the Treaty of Lisbon ${ }^{53}$. A telling confirmation of the dwindling prestige of the national rotating presidency, thus the governments of the Member States, in the new post-Lisbon EU presidency system ${ }^{54}$ is the definition of its essence as "responsibility without power" 55 .

Looking for potential areas of conflict in the relations between the President of the European Council and the presidency state, one must not overlook the requirement of cooperation of the two actors during organisation of the European Council meetings ${ }^{56}$. Although such a solution opens a channel for indirect influence on the European Council for the eliminated Head of State of Government of the country exercising presidency of the Council through the minister presiding over the General Affairs Council ${ }^{57}$, it concurrently creates a risk of misunderstanding between the President of the European Council and the state exercising the presidency of the General Affairs Council in fulfilment of their assignment in this scope. The treaties do not clarify the conditions of such a cooperation, making it impossible to precisely divide the competencies between the engaged actors, and as a result creating a risk of hierarchisation of relations between them that may arise, as it seems, from the leading role granted in this area to the President of the European Council - Art. 2(3) of the Rules of Procedure of the European Council ${ }^{58}$ clearly provides that the President establishes this close cooperation and coordination with the presidency, not the other way round. In such a scenario

${ }^{51}$ This knowledge is one of the factors that determine the bargaining power of the Member States in the European Union. See: A. Szczerba-Zawada, Pozycja ustrojowa Rady Europejskiej..., p. 122.

${ }^{52} \mathrm{~S}$. Bunse, C. Klein, op. cit. More on the benefits resulting from the performance of the rotating presidency lost by the Heads of State and Governmnet in post-Lisbon EU see: L. Jesień, op. cit., pp. 283-285.

${ }^{53}$ P. Świeboda, op. cit., p. 97.

${ }^{54} \mathrm{~K}$. Radtke, The EU'S Common Foreign and Security Policy (CFSP) after the Lisbon Treaty: Supranational Revolution or Adherence to Intergovernmental Pattern?, [in:] The EU's Lisbon Treaty. Institutional Choices and Implementation, p. 48.

${ }^{55}$ R. Grzeszczak, op. cit., p. 203.

${ }^{56}$ Art. 15(6)(b) TEU; Art. 16(6) TEU.

${ }^{57}$ L. Jesień, op. cit., p. 96.

${ }^{58}$ European Council Decision of 1 December 2009 adopting its Rules of Procedure (2009/882/ EU), O.J. 2009, L 315/51. 
of development of the relation between the President of the European Council and the President of the General Affairs Council, the position of the latter - and along with it, a national rotating presidency - will undoubtedly be further marginalised and its role may be limited to responsibilities of organisational character, eliminating from the work of the European Council these specific mechanisms, beneficial from the EU viewpoint, whose uncriticised application was related to the presidency of a given Member State ${ }^{59}$. In addition, the extension of the term of the President of the European Council and the continuity of holding the office that results from it constitutes an advantage of the President of the European Council over the rotating presidency, performed in the trio formula and in particular in the country formula ${ }^{60}$.

The changes introduced in the scope of the presidency of the European Council redefined not only the position of the presidency state in the EU organisational structures but also the statuses of the Member States per se and their mutual relations ${ }^{61}$, modifying the solutions which, for many of them, constituted confirmation of their international position ${ }^{62}$.

One must, first of all, indicate that institutionalisation of the presidency in the European Council diminishes the importance of the principle of the equality of states ${ }^{63}$ considered so far to be the greatest merit of the rotating presidency mechanism ${ }^{64}$. With the introduction of an elective term position of the President of the European Council, steering the works of this institution is not shared on the principle of equal rotation by all the Member States but becomes a structure that is external to them. Separating the presidency from the Member States deprecates the significance of the equality principle, which is important especially for smaller Member States, not only in the symbolic dimension but also in the practical one - letting them exert, within the important functions performed by the rotating presidency in the EU decision-making process, the same influence on the integration as the stronger Member States ${ }^{65}$. It would be erroneous, though, to

${ }^{59}$ K. Witkowska-Chrzczonowicz, op. cit., p. 63.

${ }^{60}$ L. Jesień, op. cit., p. 100; A. Nowak-Far, Prezydencja w Unii Europejskiej-interpretacje teoretyczne, [in:] Prezydencja w Unii Europejskiej..., pp. 165-166.

${ }^{61}$ J.W. Sap, op. cit., pp. 49-50.

${ }^{62}$ P. Świeboda, op. cit., p. 98.

${ }^{63}$ B. Crum, Accountability and Personalisation of the European Council Presidency, "Journal of European Integration" 2009, Vol. 31, No. 6, DOI: http://dx.doi.org/10.1080/07036330903199853, p. 694.

${ }^{64}$ F. Hayes-Renshaw, H. Wallace, The Council of Ministers, Basingstoke 2006, p. 155; A.M. Fernández Pasarín, The Commmutarization of the Council Presidency. Intra-Institutional Dimensions and Inter-Institutional Effect, [in:] The European Council and European Governance..., p. 94 et seq.

${ }^{65}$ S. Bunse, Small States and EU Governance. Leadership through the Council Presidency, Basingstoke 2009, DOI: http://dx.doi.org/10.1057/9780230234345, p. 38. 
assess these changes using unequivocally absolute judgements. Although it constitutes derogation from the fundamental international law principle, the formula of presidency of the European Council adopted as a result of the Lisbon reform seems not to have consequences that are so deteriorating the status of specific Member States and the decrease of their equivalent position. Such a solution does not constitute, in particular, a breach in the practice of cooperation of the EU Member States, which for the sake of efficiency of integration processes have already renounced some of the attributes that symbolise their equal position, agreeing, for an instance, to the formula of majority voting as the Council's principal decision-making procedure ${ }^{66}$. Furthermore, procedural guarantees of the election of the President of the European Council - an obligation to take into consideration the geographical and demographical diversity of the Union and the Member States during the election of the President of the European Council, as expressed in the declaration no. 6 attached to the final act of the intergovernmental conference which adopted the Treaty of Lisbon ${ }^{67}$ - constitute formal tools for balancing the interest of the bigger and smaller Member States as well as their representation when the subject decision is being made ${ }^{68}$.

\section{CONCLUSIONS}

The reforms of the EU organisational structure are, in principle, a response to the problems and challenges identified in the existing political and institutional context and related to the integration processes occurring in it ${ }^{69}$. Similar conditions constituted substantial foundation for the discussion that started a decade ago about the necessity to reform the EU presidency mechanism. Unfortunately, its final product in the form of the Treaty of Lisbon did not introduce these decisive structural solutions in the area of EU presidency, despite them being so anticipated and necessary.

In their place a system of multi-level presidency, hence multiple leadership structure $^{70}$, was adopted in which the potential benefits arising from the formation of the permanent President of the European Council disappear in front of the risks related to the imprecise delimitation of competencies of various formats of the EU presidency, especially in the area of external representation of the European Union. The regulations of the Treaty of Lisbon forming the new centres of presidency in the EU do not determine the final form of the relations between them,

\footnotetext{
${ }^{66}$ Art. 16(3) TEU.

${ }^{67}$ O.J. 2012, C 326/337.

${ }^{68}$ B. Crum, op. cit., p. 695.

${ }^{69}$ C. Closa, op. cit., p. 119.

${ }^{70}$ S. Van Hecke, P. Bursens, The Concil Presidency and the European Council. Towards Collective Leadership in the EU, [in:] The European Council and European Governance..., p. 116.
} 
although the definition of the institutional context of the presidency constitutes one of the most important determinants of its effectiveness ${ }^{71}$. As a consequence of the conflict potential of the legal solutions, the practical aspect - the way they are implemented in practice - becomes extremely important. This applies, in particular, to the relations between the permanent President of the European Council and his institutional partners. Formation of this office, justified by the need to ensure institutional continuity in the EU works as well as its recognisability in multi-pole international environment, caused many significant changes influencing the interests of both the Member States and the EU institutions and bodies ${ }^{72}$. As a result of the imprecise character of the division of the treaty prerogatives, as well as endeavours of the institutional partners to retain the status quo which may arise from this, appropriate performance of responsibilities of the President of the European Council is accompanied by many challenges, both systemic in nature - the need to more precisely define his powers in the area of the EU foreign and security policy where they overlap with the powers of the High Representative of the Union, the presidency country in the Council and the Commission President - and in the practical dimension - establishment of relations with partners in such a way that will ensure a coherent presidency system in the European Union. These issues are vital from the viewpoint of the EU as a whole, as they constitute a fundamental determinant of its functionality, both in the area of internal actions and in the field of foreign relations. In such a perspective, one must assess negatively the presidency mechanism, as formed by the existing legal regulations, which deepens its subject and functional diversity, as well as dependence of its effectiveness not on the way it is defined in normative layer (fundamental in system based on the rule of law - to which the EU as a political structure aspires at least in the declarative area $^{73}$ - but on the institutional and structural usus, formed by political arrangements, which fills in the existing legal gaps and inaccuracies pertaining to the EU presidency ${ }^{74}$. This shall be recognised correctly by newly elected president of the European Council.

\section{BIBLIOGRAPHY}

Bunse S., Small States and EU Governance. Leadership through the Council Presidency, Basingstoke 2009, DOI: http://dx.doi.org/10.1057/9780230234345.

${ }^{71}$ A. Nowak-Far, Prezydencja w Unii Europejskiej ..., p. 151.

${ }^{72}$ P. Świeboda, op. cit., p. 98.

${ }^{73}$ Art. 2 TEU.

${ }^{74}$ See e.g. Practical Arrangements between President van Rompuy and President Barroso regarding External Representation of the European Union at Presidential Level (16 March 2010), in The Treaty of Lisbon: A Second Look at the Institutional Innovations, supra n. 37, pp. 78-79. 
Bunse S., Klein C., What's Left of the Rotating Presiency? The Future of 'National' Presidencies, [in:] The European Council and European Governance. The Commanding Heights of the EU, eds. F. Foret, Y.-S. Rittelmeyer, London - New York 2014.

Closa C., Institutional Innovation in the EU: The 'Permanent' Presidency of the European Council, [in:] The EU's Lisbon Treaty. Institutional Choices and Implementation, ed. F. Laursen, Farnham 2012.

Craig P., The President of the European Council, [in:] Europe's Constitutional Challenges in the Light of the Recent Case Law of National Constitutional Courts. Lisbon and Beyond, eds. J.M. Beneyto, I. Pernice, Baden-Baden 2011,

DOI: http://dx.doi.org/10.5771/9783845233109-203.

Crum B., Accountability and Personalisation of the European Council Presidency, "Journal of European Integration" 2009, Vol. 31, No. 6, DOI: http://dx.doi.org/10.1080/07036330903199853.

Curtin P., Executive Power of the European Union. Law, Practices and the Living Constitution, Oxford - New York 2009.

Dinan D., Governance and Institutions: Implementing the Lisbon Treaty in the Shadow of the Euro Crisis, "Journal of Common Market Studies" 2011, Vol. 49,

DOI: http://dx.doi.org/10.1111/j.1468-5965.2011.02183.x.

Dudzik S., System instytucjonalny Unii Europejskiej w Konstytucji dla Europy. Zarys problematyki, [in:] Konstytucja dla Europy. Przyszły fundament Unii Europejskiej, red. S. Dudzik, Kraków 2005.

Eggermont F., The Changing Role of the European Council in the Institutional Framework of the European Union. Consequences for the European Integration Process, Cambridge - Antwerp - Portland 2012.

European Council Decision of 1 December 2009 adopting its Rules of Procedure (2009/882/EU), O.J. 2009, L 315/51.

European Parliament resolution of 7 May 2009 on the impact of the Treaty of Lisbon on the development of the institutional balance of the European Union (O.J. 2010, C 212E/12. 2008/2073(INI)).

Fernández Pasarín A.M., The Commmutarization of the Council Presidency. Intra-Institutional Dimensions and Inter-Institutional Effect, [in:] The European Council and European Governance. The Commanding Heights of the EU, eds. F. Foret, Y.-S. Rittelmeyer, London - New York 2014.

Galster J., Równowaga instytucjonalna jako kategoria doktrynalna, orzecznicza $i$ normatywna. Studium zasady Unii Europejskiej, Toruń 2008.

Galster J., Knade-Plaskacz A., E pluribus unum. Koherencja UE jako organizacji międzynarodowej, [in:] Unia Europejska: zjednoczeni w różnorodności, red. C. Mik, Warszawa 2012.

Grzeszczak R., Władza wykonawcza w systemie Unii Europejskiej, Warszawa 2011.

Hayes-Renshaw F., Wallace H., The Council of Ministers, Basingstoke 2006.

Jesień L., The European Union Presidency. Institutionalized Procedure of Political Leadership, Bern 2013, DOI: http://dx.doi.org/10.3726/978-3-0351-0531-5.

Kremczyńska K., Nowe stanowiska wysokiego przedstawiciela Unii oraz przewodniczacego Rady Europejskiej w systemie instytucjonalnym UE, „Biuletyn Polskiego Instytutu Spraw Międzynarodowych" 2009, $\mathrm{nr} 76$.

Krystyniak M., Rola przewodniczącego Rady Europejskiej w stosunkach zewnętrznych UE, „Biuletyn Polskiego Instytutu Spraw Międzynarodowych" 2003, nr 61.

Nowak-Far A., Prezydencja w Unii Europejskiej - interpretacje teoretyczne, [in:] Prezydencja w Unii Europejskiej. Instytucje, prawo i organizacja, red. A. Nowak-Far, Warszawa 2010.

Nowak-Far A., Przewodnictwo w organizacjach międzynarodowych - przeglad praktyki, [in:] Prezydencja w Unii Europejskiej. Instytucje, prawo i organizacja, red. A. Nowak-Far, Warszawa 2010.

Peterson J., Byrne A., Helwing N., International Interests: the Common Foreign and Security Policy, [in:] The Institutions of the European Union, eds. J. Peterson, M. Shackleton, Oxford 2012. 
Radtke K., The EU's Common Foreign and Security Policy (CFSP) after the Lisbon Treaty: Supranational Revolution or Adherence to Intergovernmental Pattern?, [in:] The EU's Lisbon Treaty. Institutional Choices and Implementation, ed. F. Laursen, Farnham 2012.

Rüger C., A Position under Construction: Future Prospects of the High Representative after Treaty of Lisbon, [in:] The High Representative for the EU Foreign and Security Policy - Review and Prospects, eds. G. Müller-Brandeck-Bocqut, C. Rüger, Baden-Baden 2011.

Sap J.W., The European President, "European Constitutional Law Review” 2005, Vol. 1.

Szczerba-Zawada A., Pozycja ustrojowa Rady Europejskiej w systemie instytucjonalnym Unii Europejskiej, Warszawa 2013.

Szczerba-Zawada A., Przewodniczacy Rady Europejskiej, czyli o postlizbońskiej formule przewodnictwa w Radzie Europejskiej, „Przegląd Sejmowy” 2014, nr 4.

Świeboda P., System instytucjonalny Unii Europejskiej w Traktacie z Lizbony - konsekwencje $i$ wyzwania, [in:] Traktat z Lizbony - postanowienia, ocena, implikacje, red. K. Smyk, Warszawa 2008.

The Treaty of Lisbon: A Second Look at the Institutional Innovations. Joint CEPS, EGMONT and EPC Study, Brussels 2010.

Van Hecke S., Bursens P., The Concil Presidency and the European Council. Towards Collective Leadership in the EU, [in:] The European Council and European Governance. The Commanding Heights of the EU, eds. F. Foret, Y.-S. Rittelmeyer, London - New York 2014.

Waele H. de, Broeksteeg H., The Semi-Permanent European Council Presidency: Some Reflections on the Law and Early Practice, "Common Market Law Review" 2012, Vol. 49.

Werts J., The European Council, London 2008.

Witkowska-Chrzczonowicz K., Prezydencja w Radzie Unii Europejskiej, [in:] M. Czyżniewski, K. Witkowska-Chrzczonowicz, Prezydencja Republiki Czeskiej w Radzie Unii Europejskiej. Studium prawno-politologiczne, Warszawa 2011.

Wójtowicz K., Projekt Traktatu ustanawiajacego Konstytucję dla Europy - podstawy ustroju i porzadku prawnego Unii Europejskiej, „Przegląd Sejmowy” 2004, nr 2.

\section{STRESZCZENIE}

Prezydencja Unii Europejskiej, rozumiana jako zinstytucjonalizowana procedura kierowania Unią Europejską, uległa przeobrażeniu wraz z wejściem w życie Traktatu z Lizbony, który nadał jej hybrydalny charakter. W wyniku wprowadzonych zmian unijne przewodnictwo sprawowane jest dwutorowo - przez państwa członkowskie w ramach rotacji oraz w wymiarze kadencyjnym, w którym przewodniczenie określonym instytucjom powierza się wybieranemu na określoną kadencję substratowi osobowemu danej instytucji. Przy czym wyraźnemu poszerzeniu uległ po Traktacie z Lizbony mechanizm kadencyjnej prezydencji, obejmujący obecnie także Radę do Spraw Zagranicznych i Radę Europejską.

Zinstytucjonalizowane przewodnictwo w Radzie Europejskiej, restrukturyzując przestrzeń organizacyjną dotychczasowej prezydencji UE, niewątpliwie zmieniło równowagę instytucjonalną całego systemu. Wprowadzone modyfikacje uzasadniają podjętą próbę analizy implikacji przyjętych rozwiązań, bazującą na identyfikacji potencjału relacyjnego przewodniczącego Rady Europejskiej jako ośrodka przewodnictwa w postlizbońskim systemie prezydencji Unii Europejskiej.

Słowa kluczowe: prezydencja Unii Europejskiej; przewodniczący Rady Europejskiej; wysoki przedstawiciel Unii do spraw zagranicznych i polityki bezpieczeństwa; przewodniczący Komisji Europejskiej 